\title{
Kanonické právo a spiritualita Stanislav Přibyl
}

\section{Historické souvislosti}

Člověku dnešní doby se protiví představa, že skutečnost tak intimní, jakou je spirituální život jednotlivce, by mohla být podrobena jakékoli vnější reglementaci. Katoličtí křestané a věřící dalších křestanských vyznání nežijí ve vzduchoprázdnu a často přejímají dnes všeobecně rozšířený subjektivistický náhled na vnitřní život, vzdálený představě autority, jež by závazně určovala jeho pravidla a hranice. Toho si byl vědom také papež Jan Pavel II., který jako zákonodárce Kodexu kanonického práva považoval za nutné uvést v promulgační apoštolské konstituci Sacrae disciplinae leges toto zásadní vysvětlení: „Když je tomu tak, je dostatečně zřejmé, že není cílem kodexu, aby v životě církve nahradil víru, milost, charismata nebo především lásku. Naopak, kodex má $\mathrm{v}$ záměru navodit takový pořádek $\mathrm{v}$ životě společenství církve, který dá přednost lásce, milosti a charismatům a současně usnadní jejich růst jak v životě společenství církve, tak jednotlivců, kteří k němu patří. “1

Duchovní život má bezesporu individuální, vztahovou a zvnějšku nepostižitelnou složku, která určuje jeho charakter i kvalitu. Prostor mezi lidským „jä“ a božským „Ty“ je a zůstává niterný. To vystihuje apoštol Pavel: „Nežiji už já, ale žije ve mně Kristus. A život, který zde nyní žiji, žiji ve víre v Syna Božího, který si mne zamiloval a vydal sebe samého za mne“ (Ga 2,20). ${ }^{2}$ Je to ovšem týž Pavel, který zároveň dbal na to, aby se vnější projevy duchovního života věŕících varovaly chaosu a neuspořádanosti: „Kdyby se celá církev sešla ve shromáždění a všichni by mluvili ve vytržení a přišli tam lidé nezasvěcení a nevěřící, cožpak neřeknou, že blázníte?“ (1 K 14,23) Sám Pavel stanoví na mnoha místech svých listů závazná pravidla pro uspořádání nejrozmanitějších oblastí křestanského života, mezi nimi i tak „spirituálních“, jako je např́iklad eucharistické shromaždování (1 K 11,17-34).

Velmi záhy se v dějinách církve osvědčil duchovní život trávený v samotě, jak o tom svědčí nejprve vznik poustevnictví (eremitství), které ovšem brzy přerůstá do forem společného života s pevně danými pravidly. Zakladatelem takového klášterního (cenobitského) života se stal egyptský asketa Pachómios ( $†$ kolem r. 346). Smyslem této nové a v dějinách světového křestanstva mnohostranně osvědčené podoby duchovního usilování byla jistě i minimalizace př́ležitostí $\mathrm{k}$ individuálním selháním. Jejich korektivem měl být právě komunitní život, podléhající společným pravidlům,

Kodex kanonického práva. Úřední znění textu a překlad do češtiny, Praha: Zvon, 1994, s. XV.

2 „Pavel zde formuluje velmi osobně, hovoří však v zastoupení všech věřících. Základem tohoto tak výrazného a působivého vyjádření vztahu ke Kristu je jistě jeho osobní zkušenost s Kristem, počínající setkáním se Zmrtvýchvstalým u Damašku. Pavel tak ukazuje, jak chápal víru v Krista a její účinky v životě věrících.“ Ladislav TICHÝ, List Galatským, Praha: Centrum biblických studií AV ČR a UK v Praze, 2016, s. 52. 
regulím (odtud české slovo „řehole“). ${ }^{3}$

Klasické dílo Tomáše Kempenského „O následování Krista“ (De imitatione Christi libri quattuor) svědčí o tom, že také kontemplativní středověk si nedovedl představit duchovní zdokonalování bez solidní opory v přísném zachovávání řeholních pravidel: „Víš, jak to dělají ti řeholníci, kteří svůj život podřídili přísné řeholní kázni? Zřídkakdy vycházejí, žijí v odloučení, jedí velice skrovně, oblékají hrubý šat, hodně pracují, málo mluví, dlouho bdí, časně vstávají, prodlévají na modlitbách, mnoho čtou a přičiňují se o dokonalou sebekázeň. “4

Protestantská reformace odvrhla řeholní způsob života, oproti němuž vyzdvihla laický prvek a manželský život. Augsburská konfese se přitom odvolává nejen na biblický Pavlův text, nýbrž také na prestižní kanonickoprávní autoritu středověku, Graciánův dekret: „Kdysi se (do klášterů) scházeli, aby se učili (Písmu); nyní předstírají, že jest to způsob života zřízený k zasloužení milosti a spravedlnosti a dokonce hlásají, že je to stav dokonalosti, a velice jej vyvyšují nad každý jiný způsob života ustanovený Bohem (...); Toto pak jest Boží rozkaz: ,Z př́činy smilstva jeden každý manželku svou měj (a jedna každá měj muže svého)‘ (1 Kor. 7,2). (...) Církevní zákony učí, že při každém slibu činí právo vyššího výjimku; proto tím méně platí tyto sliby proti rozkazům Božím. " 5 Tridentský koncil naproti tomu usiloval o vytvoření solidního právního rámce pro obnovení řeholního života. Dekret Eadem sacrosancta vydaný při 25. zasedání sněmu (1563) uvádí: „Protože svaté synodě není neznámo, kolik Božího světla a užitku v církvi vzchází z klášterů zbožně založených a dobře spravovaných, uznala za nezbytné (aby tam, kde stará a řeholní kázeň upadla, snáze a rychleji byla obnovena, a tam, kde byla zachována, aby s větší stálostí vytrvala) přikázat, jako už tímto dekretem přikazuje, aby všichni řeholníci, jak muži, tak ženy, uspořádali a žili svůj život podle předpisů řehole, na kterou složili sliby. “6 Je třeba zdůraznit, že koncil vydává dekret v době, kdy se již šírí reformní dílo nejvýznamnějších a duchovně nejplodnějších představitelů katolické řeholní obnovy, např́klad Ignáce z Loyoly, Terezie z Ávily, Filipa Neriho a jejich četných současníků a následovníků. Obnovují se staré a vznikají nové řehole i nové formy řeholního života.

Je zřejmé, že k tomu, aby katolická reforma zapustila pevné kořeny, bylo nejen potřeba obnovit kázeň řeholního i kněžského života, nýbrž poskytnout př́ležitost také laikům, aby i oni měli možnost věnovat se duchovnímu životu a dostalo se jim vedení přiměřeného jejich stavu. Jinou cestou se ubíralo pravoslaví, které je na rozdíl od západního křestanství natolik utvářeno monastickou asketickou spiritualitou, že pro formální rozlišování spiritualit jednotlivých „stavư křestanů postrádá motivaci. ${ }^{7}$ Zato $\mathrm{v}$ katolickém prostředí $\mathrm{k}$ reakci na jednostrannou protestantskou emfasi laického prvku došlo. Není snad významnější př́ručky, která měla po dlouhá staletí vliv na duchovní život laiků, než „Úvod do zbožného života“ (též Filothea) Františka Saleského. ${ }^{8}$ Nejen tato proslulá a nesčetněkrát vydávaná kniha, nýbrž i pozdější návody duchovního života, určené

3 „Požadavek rovnosti všech mnichů vylučoval individuální asketické zanícení i všelijaké bizarní asketické výkony. (...) Autoritou, která něco vyžaduje, je nyní řehole a nad ní představený. Pro žádného mnicha, i toho nejdokonalejšího, od toho nikdy neexistuje dispens.“ Karl Suso FRANK, Dějiny křestanského mnišství, Praha: Benediktinské arciopatství sv. Vojtěcha \& sv. Markéty, 2003, s. 30-31.

5 Vyznání víry podané nepřemožitelnému císaři Karlu V., rozmnožiteli říše, na sněmu v Augsburce roku 1530, čl. XXVII., „O klášterních slibech“, č. 5 a č. 7, in: Rudolf ŘíČAN, Čtyři vyznání (Augsburské, Bratrské, Helvetské a České). Se čtyřmi vyznáními staré církve a se Čtyřmi články pražskými, Praha: Komenského bohoslovecká evangelická fakulta, 1951, s. 96-97.

6 Antonín Ignác HRDINA (přel.), Dokumenty Tridentského koncilu. Latinský text a překlad do češtiny, Praha: Krystal OP, 2015 , s. 245.

7 „Mnišství je neoddělitelnou součástí a má normativní hodnotu pro všechny jako jistý stav duše, která si vnitřně osvojuje mnišskou duchovnost. Zachování čistoty srdce, mysli, panenství a mnoha dalších duchovních kvalit bylo nejen záležitostí mnichů, nýbrž i ostatních členů církve (...). “Štefan PRUŽINSKÝ, Pravoslávna duchovnosț. Cesta k spasitelnej jednote člověka s Bohom II., Košice: Univerzita P. J. Šafárika v Košiciach, 1992, s. 85.

8 „Úvod do zbožného života poprvé vyšel v roce 1609, ale definitivní vydání, jež připravil sám František Saleský, bylo pořízeno v roce 1619. Kniha je určena laikům. Svatý František Saleský je patrně prvním duchovním autorem, který napsal pojednání o laické spiritualitě.“ Jordan AUMANN, Křstanská spiritualita v katolické tradici, Praha: Nakladatelství Karolinum, 2000, s. 198. 
širokým vrstvám katolických věřících, mohly sice představovat pro mnohé z nich dobrovolně přijatou „reguli“ soukromého duchovního života, avšak dodržování v nich doporučených způsobů duchovního prožívání a modlitebních praktik samozřejmě nemohlo být kanonickoprávně uchopitelné.

Od soukromé inspirace díla Františka Saleského pro osobní zbožnost věřících je odlišný „osud“ exercicií Ignáce z Loyoly. Těm se dostalo roku 1538 schválení papeže Pavla III., přičemž následný vývoj vbrzku ukázal, že jsou vhodným nástrojem duchovního života, který je možno uplatnit rovněž formou uložení právní povinnosti. Kodex kanonického práva z roku 1917 zavazuje $\mathrm{k}$ účasti na duchovních cvičeních celkem osm kategorií věřících, mezi nimiž ovšem scházejí laici neaspirující na řeholní či duchovenskou formu života. Do podoby právem uložené povinnosti se tak exercicie „přetavily“ pro seminaristy, svěcence, diecézní kněze, postulanty, novice, řeholníky, faráře a kanovníky. ${ }^{9}$ Tento dějinně první kanonickoprávní kodex katolické církve si vytkl za cíl především „pročistit“ dosavadní právní předpisy, jejichž nejvýznamnější část ovšem pocházela ze svodu Corpus iuris canonici, obsahujícího středověké právo. V případě uložení povinnosti exercicií se však již jedná o předpisy plynoucí z potřeby novověké církevní reformy, které se do kodexu rovněž prosadily. Je zřejmé, že se v průběhu času již dostatečně osvědčily. Nový kodex z roku 1983 je pak v záležitosti exercicií poněkud méně podrobný, navíc v něm již chybí možnost trestního pokání „vykonat duchovní cvičení po několik dnů v zbožném nebo řeholním domě“. 10

Povinnost vykonávat alespoň každoroční exercicie je v každém případě mimořádnou a velmi silnou transpozicí projevů konkrétní řeholní spirituality za hranice řeholního společenství, ve kterém vznikla. Kodex z roku 1983 rovněž vnáší duchovní cvičení do života farností tak, aby se jejich spiritualita stala prŕstupnou i laikům. Formuluje tento proces jako organizační povinnost farářou, kteří mají „uspořádat v určitých dobách kázání, zvaná duchovní cvičení a svaté misie, nebo jiné formy kázání, přizpơsobené potřebám doby." "Zmíněny jsou zde také svaté misie (sacrae missiones), které jsou projevem jiné než jezuitské řeholní spirituality, totiž pastoračně laděného praktického př́stupu kongregace redemptoristů. ${ }^{12}$ Zvláštní ohled bere kanonické právo dodnes také na specifický projev života žebravých řádů, ${ }^{13}$ jejichž spiritualitě přístupu $\mathrm{k}$ hmotným statkům vychází právo vstříc poskytnutím výjimky ze všeobecného zákazu vyžadovat kýmkoli př́ispěvky na libovolný církevní účel bez písemného svolení ordináře. ${ }^{14}$

\section{Východní křestanství a liturgie církve}

Katolické východní církve jsou nositelkami specifických spiritualit: „Honosí se totiž úctyhodnou starobylostí a vyzařuje z nich apoštolská tradice zprostředkovaná církevními otci; ta tvoří součást božsky zjeveného a nedílného dědictví všeobecné církve. “15 Zvnějšku nejnápadnějším projevem

9 CIC 1917, cc. $13674^{\circ} ; 1001 ; 126 ; 541 ; 571 \S 3 ; 595 \$ 1,1^{\circ} ; 465 \$ 3 ; 420 \$ 1,7^{\circ}$ et $\$ 2$.

10 CIC 1917, c. $2313 \$ 1,5^{\circ}$. Bernard Bolzano (1781-1848) ve své autobiografii uvádí: „(...) jak mu církevní vrchnost předepsala exercicie, při nichž měl přemítat o svých omylech, on se však jen znovu přesvědčil o své nevině, za kteroužto nepokoru mu byly uloženy exercicie nové, in: Martin C. PUTNA, Česká katolická literatura 1848-1918, Praha: Torst, 1998, s. 48.

11 CIC 1983, c. 770.

12 „Význam redemptoristů jako znamenitých lidových misionářů, stavovských kazatelů a zpovědníků, šiřitelů nové úcty a zbožnosti v duchu sv. Alfonse, k čemuž napomáhali i jako spisovatelé misionárních knížek a překladatelé, je neocenitelný.“ Bohumil ZLÁMAL, Př́ručka českých církevních dějin - VI. Doba probuzenského katolicismu (1848-1918), Olomouc: Matice cyrilometodějská, 2009 , s. 93.

13 „V užším slova smyslu se jimi rozumí ty řády, kterým je zakázáno vlastnictví společného majetku nebo pobírání stálých př́imů, tedy františkáni, minorité a kapucíni, a které jsou tak odkázány na sbírání almužen jako zdrojů své obživy. Jejich privilegium sbírání almužen zůstává nedotčeno, ačkoliv již méně odpovídá dnešním poměrům. “ Hans HEIMERL - Helmuth PREE - Bruno PRIMETSHOFER, Handbuch des Vermögensrechts der katholischen Kirche, Regensburg: Verlag Friedrich Pustet, 1993, s. 192-193.

14 CIC 1983, c. 1265.

15 Orientalium Ecclesiarum 1. 
jejich duchovního života jsou specifické liturgické obřady, proto se zažilo označování těchto církví jako „rituálních“, tedy jako církví slavících rozmanité podoby obřadů, které se postupně utvářely v různých oblastech křestanského Východu. Navíc má větší část katolických východních církví ještě „druhou“, protější podobu: například katolíci byzantského ritu nacházejí svůj protějšek v autokefálních pravoslavných církvích, působících bez zachování jednoty s Římem a vedení papeže. Kodex kánonů (katolických) východních církví z roku 1990 ovšem nezužuje pojem ritu na samotnou liturgii: „Obřad je dědictví liturgické, teologické, duchovní a disciplinární, způsobené odlišnou kulturou a historickými okolnostmi národů, a proto se vyjadřuje osobitým způsobem žité víry u každé jednotlivé církve sui iuris. " ${ }^{16}$ Je však třeba zdo̊raznit, že na utváření spirituality východních křestanů má liturgie zcela zásadní vliv. ${ }^{17}$ Specifická spiritualita je tak podle zákonodárce př́mo pojmovým znakem jednotlivých ritů, které se člení do pěti dějinně utvořených „rodin“: „Obřady, o kterých pojednává kodex, jsou ty, které vycházejí z tradic alexandrijské, antiochijské, arménské, chaldejské a konstantinopolské (byzantské), jestliže není stanoveno jinak. "18 Také v západní (latinské) církvi lze místy nalézt svébytné liturgické obřady, jakým je například ambroziánský ritus $\mathrm{v}$ milánské arcidiecézi. I ty přirozeně ovlivňují specifický duchovní život věřících. Vlivem postupné centralizace západní církve v průběhu prvního tisíciletí však jejich „celebrujícími“ církvemi nejsou samostatné církve „svého práva“ (sui iuris); tyto obřady tak nejsou prríčinou zrrízení autonomních církví, jako je tomu na Východě. ${ }^{19}$

Oba platné kanonickoprávní kodexy potvrzují jako jedno ze základních, „ústavních“ práv věřících právo na vlastní obřad a na vlastní spiritualitu: „Křestané mají právo na bohoslužby podle předpisů vlastního obřadu, schváleného zákonnými pastýři církve, a na vlastní způsob duchovního života, pokud je v souladu s učením církve. ${ }^{20}$ Právo na bohoslužby předpokládá také povinnost posvátných služebníků řídit se liturgickými knihami schválenými př́slušnou církevní autoritou. „Kreativita“, která překračuje rámec liturgického práva, zcela protiřečí zásadnímu principu, podle něhož „ani kněz nesmí v liturgii o své vưli nic přidávat ani ubírat ani měnit“. ${ }^{21}$ Pro disciplínu dnešní podoby liturgie západního obřadu je neustále zapotřebí dbát na pevný disciplinární rámec, který by zaručil celebraci římského ritu v souladu s liturgickými předpisy: „Všichni věřící mají právo na pravou liturgii a především na slavení mše svaté tak, jak to církev chtěla a ustanovila a jak je to nařízeno v liturgických knihách a dalších zákonech a normách. Stejným způsobem mají katolíci právo, aby se pro ně sloužila obět mše svaté v neporušené podobě a v plné shodě s učením učitelského úřadu církve (...) “22

Některé skupiny katolických věřících římského západního obřadu preferují i nadále slavení liturgie podle potridentského Misálu sv. Pia V., naposledy revidovaného Janem XXIII. roku 1962. Papež Benedikt XVI. považoval za vhodné rozšírit a usnadnit přístup věřících $\mathrm{k}$ této „tradiční" liturgii (usus antiquior). Z církevněprávního hlediska se zde jedná o pomoc při realizaci uvedené-

16 CCEO, c. $28 \$ 1$.

17 „Když se klanějí východní křestané v této atmosféře bohaté na mysticismus, skrze který se přibližuje nádhera nepř́stupného božského majestátu a svatosti, svědčí tím o oslavě a posvěcení stvoření, o majestátním zjevení Boha, který je prostupuje, posvěcuje, zbožštuje proměňujícím světlem své božské milosti. Nejedná se pouze o ,přijetí svátostí, ale zvyk žít v liturgickém prostředí, které obklopuje tělo i ducha a proměňuje víru v konkrétní vizi duchovní krásy a radosti.“ Robert F. TAFT, Život z liturgie. Tradice Východu i Západu, Olomouc: Refugium Velehrad-Roma, 2008, s. 167.

18 CCEO, c. $28 \$ 2$.

19 „Z tohoto pohledu pak mohou existovat i takové rituální církve, které nemají vlastní právo a vlastní nezávislé vedení, mají však vlastní obřad - takovou je např́klad italská Ambroziánská církev.“ Jiří DVOǨÁČEK, Východní kanonické právo. Úvod do studia, Praha: Apoštolský exarchát řeckokatolické církve a Institut sv. Kosmy a Damiána, 2014, s. 44.

20 CIC 1983, c. 214; CCEO, c. 17.

21 Sacrosanctum concilium $22 \$ 3$.

22 Redemptionis sacramentum. Instrukce o tom, co se má zachovávat a čeho je třeba se vyvarovat ohledně eucharistie, dokument Kongregace pro bohoslužbu a svátosti z 25. března 2004, čl. 12, Praha: Česká biskupská konference, 2005, s. 6. 


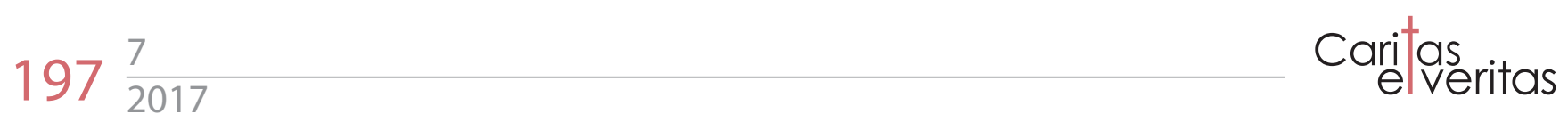

ho práva na vlastní ritus a spiritualitu podle vlastní volby. Tomu také odpovídá skutečnost, že papež v apoštolském listu z roku $2007^{23}$ nepřistupuje ihned k výčtu jednotlivých normativních článků, nýbrž nejprve oceňuje duchovní bohatství tohoto obřadu: „Je také známo, že latinská liturgie byla $\mathrm{v}$ různých jejích formách po všechna staletí trvání křestanské církve stimulem v duchovním životě mnoha světců, posilovala tolik národů v ctnostném náboženském cítění a obohacovala jejich zbožnost. “24 Instrukce Papežské komise Ecclesia Dei uvádí vzájemnou souvislost obou podob ř́mského ritu: „Texty Ř́mského misálu vyhlášeného papežem Pavlem VI. a texty obsažené v posledním vydání za Jana XXIII. jsou dvě formy římské liturgie, nazývané řádná (ordinaria) a mimořádná (extraordinaria): dvě formy jediného římského obřadu, které existují jedna vedle druhé. Jedna i druhá vyjadřují to, jak se církev modlí (lex orandi). Pro své úctyhodné a starobylé užívání má být mimořádná forma zachovávána s náležitou úctou. " 25

Zatímco od šestnáctého století se vůči východním církvím, které se navrátily do plné jednoty s Apoštolským stolcem, prosazovala nepatřičná tendence „latinizace“26 zejména v období po Druhém vatikánském koncilu se ustálila tendence opačná. Děje se to za situace, kdy římskému obřadu přináležejí vysoké stamiliónové počty věřících v celém světě, zatímco souhrnný počet věřících všech katolických východních církví sui iuris dosahuje sotva třiceti miliónů. Tím se pohledem současného kanonického práva a komplexního pastoračního přístupu stávají členové těchto církví de facto právně chráněnou menšinou. Z některých oblastí Blízkého a Středního východu se vzhledem k obtížným životním podmínkám křest’ané stěhují především na Západ, do Evropy a severní Ameriky. Autentické místní církve zemí původu se tak vylidňují a vymírají. Za těchto okolností vyvstal před katolickou církví nesnadný úkol specifické pastorace těchto skupin věřících. ${ }^{27} \mathrm{~V}$ kodexu pro katolické východní církve se deklaruje odhodlání tyto tradiční projevy víry chránit: „Obřady východních církví jako dědictví univerzální Kristovy církve, v němž září apoštolská tradice předaná skrze církevní otce a která potvrzuje božskou jednotu katolické víry v různosti, se mají s úctou dodržovat a podporovat. " 28

Kodex pro latinskou církev přislibuje zajištění pastorace pro katolické východní křestany tak, aby mohl být zabezpečen a podporován i jejich duchovní život. Diecéznímu biskupovi například ukládá následující povinnost: „Jestliže má ve své diecézi věřící různého obřadu, postará se o jejich duchovní potřeby prostřednictvím kněží nebo farností tohoto obřadu nebo ustanovením biskupského vikáře “ ${ }^{29} \mathrm{Na}$ teritoriích, kde dominuje církev římského obřadu, se ustavují další partikulární církve katolických obřadů: „Na témže území mohou být zř́izeny, pokud je to užitečné, podle rozhodnutí papeže a po projednání s biskupskými konferencemi, jichž se věc týká, i jiné místní církve, různé podle obřadu nebo z jiného podobného důvodu. “30 Pro plnění povinnosti

23 Motu proprio Summorum pontificum, in: Acta Apostolicae Sedis 90 (2007), s. 776-781; in: Acta České biskupské konference 3/2008, s. 50-54.

24 Motu proprio Summorum pontificum, in: Acta České biskupské konference 3/2008, s. 50.

25 Papežská komise Ecclesia Dei: Instrukce k provádění apoštolského listu (motu proprio) papeže Benedikta XVI. Summorum pontificum, 30. dubna 2011, in: Acta biskupské konference 6/2011, s. 123.

26 „Pojetí nadřazenosti latinské církve a latinského obřadu mělo konkrétní důsledky v disciplíně církve. Vzhledem k tomu, že latinský obřad byl nadřazen řeckému, bylo například zakázáno někoho převést z latinské církve do řecké, protože by bylo nemyslitelné nahradit nadřazený obřad nižším. "John FARIS, The Latin Church sui iuris, The Jurist. Studies in Church Law and Ministry, Vol. LXII, Washington D.C., 2002, s. 280-293, s. 281.

27 „Je velmi pravděpodobné, že stejně jako vymřely např. církve v Núbii, v Kartágu či v Pentapolis, zaniknou i některá dnešní společenství věrících, ztrácející svou životaschopnost (toto nebezpečí aktuálně hrozí např. církvi italo-albánské katolické), a naopak jiná, v současné době sice zařazená do některé již existující církve sui iuris, avšak zároveň nepodléhající jejímu nejvýše postavenému představiteli, ale přímo nejvyšší církevní autoritě, tedy Apoštolskému stolci (např. apoštolský exarchát v České republice), mohou být v budoucnu povýšena na samostatnou církev sui iuris (...). "Miloš SZABO, Východní křestanské církve. Stručný prehled sjednocených i nesjednocených církví křestanského Východu, Praha: Nakladatelství Karolinum, 2016, s. 17-18.

28 CCEO, c. 39.

29 CIC 1983, c. $383 \$ 2$.

30 CIC 1983 , c. $372 \$ 2$. 
účasti na běžném nedělním eucharistickém slavení však může každý katolík svobodně volit jakýkoli katolický obřad: „Křestané se mohou zúčastnit mše a přijmout svaté přijímání v kterémkoliv katolickém obřadu (... “.31

Rozvíjející se ekumenické vztahy s nesjednocenými východními církvemi vedly k deklaraci sebeomezení na katolické straně, jež na křestanském Východě napříště nehodlá rozvíjet samostatné misie: „Pastorační aktivita katolické církve jak latinské, tak i východní, už nemá za cíl přimět věřící $\mathrm{k}$ přestupu $\mathrm{z}$ jedné církve do druhé a nesměřuje již $\mathrm{k}$ proselytismu mezi pravoslavnými. Jejím cílem je uspokojit duchovní potřeby svých vlastních věřících, ne však vůle k expanzi na úkor pravoslavné církve. “32 V této souvislosti je navíc třeba upozornit na skutečnost, že některé unie východních církví s Římem trvají již po dlouhá staletí a jejich duchovní život mezitím doznal i u nich svébytných podob, nebot také východní křest’anství se neprojevuje strnule a rovněž ono prodělává postupný vývoj. ${ }^{33}$

\section{3. Řeholní a laická spiritualita}

Na křestanském Západě se ve druhém tisíciletí uskutečnil mimořádně artikulovaný rozvoj nejrozmanitějších forem řeholních spiritualit. Na jedné straně lze hovořit o úctyhodném duchovním bohatství, na druhé straně však postupně docházelo k povážlivé vnitřní fragmentaci života církve. Tuto tendenci vystihl již IV. lateránský koncil (1215), který stanovil obecný zákaz zakládání nových řádů: „Aby se prŕlišná různost řeholních řádů nestala příčinou vážného zmatení v církvi Boží, do budoucna př́ísně zakazujeme zakládání nových řádio. Kdo by se chtěl rozhodnout pro řeholní život, necht' si zvolí některou z již schválených řeholí. “34

Další osmisetletý vývoj přinesl v některých obdobích až překotné vlny zakládání dalších a dalších řádů, společností, kongregací a institutů. Kodex kanonického práva se pokusil převést toto překypující bohatství na nejvyšší společné jmenovatele rámcovou úpravou společenství evangelijních rad, která je doširoka strukturována dělením na řeholní a sekulární instituty zasvěceného živo$\operatorname{ta}^{35}$ a společnosti apoštolského života. ${ }^{36} \mathrm{~V}$ rámci těchto tři kategorií se společenství dělí jednak na mužská a ženská, a dále na společenství papežského práva (exemptní) a diecézního práva. ${ }^{37}$ Svatý stolec si navíc vyhrazuje schvalování př́ípadných nových způsobů zasvěceného života. ${ }^{38}$ Klasické dělení na řehole aktivní a kontemplativní není v současné kodexové úpravě zakotvené $\mathrm{v}$ takto schematicky ustálené duální podobě. Rozrůznění je bohatší, nebot̉ společnosti zasvěce-

31 CIC 1983, c. 923 .

32 V libanonském Balamandu roku 1993 podepsaný konvergenční dokument Uniatismus, unijní metoda minulosti a současné hledání plného společenství, čl. 22, in: Walerian BUGEL (přel.), Ekumenické konsensy I. Katolicko-pravoslavné konsensy na celosvětové úrovni, Olomouc: Refugium Velehrad-Roma, 2001, s. 95.

33 „Na Západě se duchovní školy rozlišovaly podle řeholních řádů nebo podle národností. Na Východě řády nejsou; rozlišují se národnosti, ale nacionalismus nezasáhl duchovní nauku. (...) A přece by nebylo nic mylnějš́ího, než kdybychom chtěli vtěsnat východní spiritualitu do jediného systému, který by měl tytéž zásady.“ Tomáš ŠPIDLÍK, Spiritualita křestanského Východu, Rím: Křestanská akademie, 1983 , s. 30.

34 Concilium Lateranense IV, 13: De novis religionibus prohibitis, in: Giuseppe ALBERIGO - Giuseppe L. DOSSETTI - Perikles-P. JOANNOU - Claudio LEONARDI - Paolo PRODI, Concilium oecumenicorum decreta, Bologna: Edizioni Dehoniane, 2002 , s. 242.

35 CIC 1983, c. 607-730.

36 CIC 1983, c. 731-746.

37 Exempce má svůj původ v clunyjské reformě řeholního života 10.-11. století: „Klášter, zasvěcený apoštolům Petrovi a Pavlovi, byl postaven pod libertas Romana, tj. pod ochranou papežského stolce. Papež se nestal pánem či vlastníkem kláštera, ale garantoval mu svobodu a nezávislost před nároky světské i duchovní moci. "Drahomír SUCHÁNEK - Václav DRŠKA, Církevní dějiny. Antika a středověk, Praha: Grada Publishing, 2013, s. 246.

38 CIC 1983, c. 605 zde reprodukuje dekret Druhého vatikánského koncilu o přizpůsobené obnově řeholního života Perfectae caritatis, 19. „Je třeba zdůraznit, že tato norma se diametrálně odlišuje od četných předkoncilních návrhů, doložených v synodálních aktech II. vatikánského koncilu, které naivně nabádaly k opačným snahám, totiž k důslednému zákazu dalšího zakládání.“ Domingo Javier ANDRÉS, Il diritto dei religiosi. Commento esgetico al Codice, Roma: Ediurcla, 1996, s. 55. 
ného života „důsledněji následují Krista bud’ v modlitbě, nebo v hlásání Božího království nebo v prokazování dobra lidem nebo v setkávání s lidmi“ ${ }^{39}$ Zasvěcený život nepředstavuje „útěk ze světa" (fuga mundi), ${ }^{40}$ nabývá však různých podob distance od světa podle povahy a spirituality konkrétní formy zasvěceného života: „Veřejné svědectví, které mají řeholníci vydat Kristu a církvi, s sebou přináší odloučení od světa, odpovídající povaze a účelu každé společnosti. " ${ }^{41}$ Spiritualita musí navíc vyzařovat zřetelný ekleziální rozměr, nemá spočívat především v individualistickém úsilí o asketické sebezdokonalování, ${ }^{42}$ nebot zasvěcený život „patří k životu a svatosti církve“.43 Všechny formy zasvěceného života totiž „přinášejí Bohu zvláštní obět chvály, osvěcují Boží lid hojnými plody svatosti a podněcují ho př́íladem a rozšiřují ho tajemnou apoštolskou plodností (fecunditas apostolica)“. ${ }^{4}$

Kodex formuluje základní ústavní strukturu Božího lidu ve dvou základních kategoriích: jsou to duchovní (klerici) a laici, zatímco zasvěcené osoby nepředstavují jakési tertium quid, nýbrž náležejí do jedné z nich - řeholnice a řeholní bratři zůstávají laiky, řeholní kněží se stali kleriky. ${ }^{45}$ Kodex kánonů pro východní církve ovšem pojednává řeholní život v poněkud jiném kontextu a rozděluje křestany de facto na „trojí lid“: klerici „jsou určeni k tomu, aby se účastnili na poslání a moci Ježíše Krista pastýře a stali se služebníky církve“" ${ }^{46}$ laikům „je vlastní světská a speciální úloha, žijí ve světě a podílejí se na misijním díle církve“, ${ }^{47}$ řeholníci „se vzdávají světa a úplně se zasvěcují, aby dosáhli dokonalosti v lásce službou Božímu královstvi““ ${ }^{48}$ Ani toto pojetí neimplikuje strohé rozdělení na kontemplativní a aktivní způsob zasvěceného života. V porovnání s úlohou laiků, pro jejichž specifické postavení je aktivita přímo pojmovým znakem, se zde řeholní život sice nemusí jevit jako projev „útěku ze světa“, rozhodně však je pojímán jako volba preferující ústraní, v němž jedině lze dosáhnout zcela soustředěného duchovního života. Takové spiritualitě se pak zcela oddávají poustevníci, kteří se „úplně odevzdávají nebeské kontemplaci a úplně se odlučují od lidí a světa“" 49

Apoštolská adhortace Jana Pavla II. Vita consecrata z roku 1996, která je výsledkem předchozích jednání synody biskupů o zasvěceném životě, se rovněž přiklání ke „trojdělení“ Božího lidu, které zde ovšem nenavozuje samy ústavní základy církve, jak to činí především latinský Kodex kanonického práva, nýbrž spíše existenci a působení tří různých povolání, tří „stavů křestanského života“: „Povolání k laickému životu, ke svátostnému kněžství a k zasvěcenému životu mohou sloužit jako př́klady toho, že jednotlivá povolání, každé stejným a přece jiným způsobem, at na ně pohlížíme jednotlivě nebo společně, všechny pocházejí z jednoho zdroje, totiž z bohatství daru Božího. " ${ }^{50} \mathrm{~V}$ každém případě je Vita consecrata v tomto bodě bližší členění struktury Kodexu kánonů východních církví. Tradiční katolické pojetí naopak zasvěcený

39 CIC 1983, c. 577.

40 „Toto odpoutání se ,od světa ( ...) není kvietismus, ani útěk ze strachu před překážkami, ani odpor proti lidskému společenství. Naopak, je to shromáždění sil. Aby mohl křestan svobodně ve světě žít, musí nad ním ve svém nitru nejdříve zvítězit." Předmluva, in: Tomáš KEMPENSKÝ, Následování Krista, přel. Josef PERNIKÁŘ, Olomouc, 1990.

41 CIC 1983, c. $607 \$ 3$.

42 „Takto chápané evangelní rady nemají individuální výměr ani nejsou asketickým prostředkem k dosažení osobní spásy, ale sjednocují člověka novým způsobem s tajemstvím církve a spásným Kristovým dílem a zavazují ho ke službě budování církve a spáse světa." Bronisław Wenanty ZUBERT, Řeholní právo. Instituty zasvěceného života a společnosti apoštolského života, Olomouc: Matice Cyrilometodějská, 1996, s. 20.

43 CIC 1983 , c. $207 \$ 2 ;$ c. $574 \$ 1$.

44 CIC 1983, c. 674.

45 CIC 1983, c. 207.

46 CCEO, c. $323 \$ 1$.

47 CCEO, c. 399.

48 CCEO, c. 410.

49 CCEO, c. 481.

50 Vita consecrata 31. 
život jako takový mezi stavy křestanského života nezařazovalo. ${ }^{51}$

Je zřejmé, že křestanské východní církve znají jeden typ mnišství, které se nerozrůzňuje do četných řeholí rozmanitých observancí. V tomto smyslu ani není důvod nazývat řeholi například v církvích byzantského obřadu za „basiliánskou“, protože je zde řeholí de facto jedinou. Kromě byzantské tradice jsou to zejména tradice staroorientálních církví dalších východních obřadů,

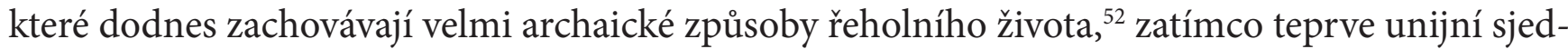
nocení s Římem přineslo některým katolickým východním církvím otevřenost vưči dalším formám zasvěceného života, jejichž původ lze nalézt výlučně na křestanském Západě. Proto počítá kodex pro východní církve vedle řeholních řádů rovněž s existencí kongregací, ${ }^{53}$ se „sdruženími společného života na způsob řeholníkư", tedy obdobami společností apoštolského života, ${ }^{54}$ a rovněž se sekulárními instituty. ${ }^{55}$

Církev na Západě však rozvíjela také formy společného života křestanů laiků. Kodex kanonického práva z roku 1917 schematizoval jejich právní ukotvení do tř́i základních podob: světské třetí řády (tertii Ordines), bratrstva (confraternitates) a zbožné jednoty (piae uniones). ${ }^{56}$ Zákonně zakotvené privilegium prozrazuje, že eucharistická úcta se v katolické církvi na Západě již dlouho považovala za nejpřednější z forem spirituálního života také pro laické křestany: „Je-li průvod, v němž se nese Nejsvětější Svátost, má bratrstvo Nejsvětější Svátosti pořadí i před arcibratrstvy. “57

Jestliže v době platnosti kodexu z roku 1917 prožíval katolický laikát svoji zbožnost sdružen v nejrozmanitějších sodaliciích a mariánských družinách, které se řídily uvedeným právním režimem, pak jedním z nových fenoménů, které se projevily v období kolem Druhého vatikánského koncilu, jsou různá církevní hnutí (movimenti) a další obdobné skupiny věřících, pěstující specifické formy spirituality. Jejich života se účastní klerici i laici a mnohé z nich využívají pro upevnění svojí ekleziální identity možností kanonickoprávního postavení v rozmanitých podobách sdružení křestanů. ${ }^{58}$

Z nepřeberného množství spiritualit se v katolické církvi prosadila od konce 60. let 20. století také tzv. charismatická obnova, která do katolické církve mnohdy spíše eklekticky přenesla určující prvky převzaté z praxe letničního křestanství severoamerické provenience. Katolická charismatická obnova by měla usilovat o harmonizaci této specifické spirituality, zdůrazňující moment duchovního i tělesného uzdravení, s tradičním katolickým pojetím, zejména v oblasti svátostného života církve. ${ }^{59}$ Přesto však může být skutečné jednání některých skupin „neukázněné, a proto církev vyjadřuje odhodlání využívat k usměrňování jejich praxe také disciplinárních prostředků: „Je třeba se důsledně vyhýbat záměně volných neliturgických modliteb za přesně stanovená liturgická slavení. Je kromě toho třeba, aby v jejich průběhu nedocházelo, především ze strany toho,

51 „Člověk má před sebou otevřeny tř̌i stavy: stav svobodný ve světě, stav manželský a stav kněžský. Životních povolání má před sebou mnoho. Na správné volbě stavu a povolání závisí štěstí životní a také věčná spása." František TOMÁŠEK, Katolický katechismus, Praha: Česká katolická charita, 1968, s. 123.

52 „Etiopská klášterní tradice je jakýmsi živým muzeem prvotního křest’anství. (...) Tak jako byzantské kláštery, i etiopské kláštery na první pohled působí dojmem jednotvárnosti duchovního života. Silný důraz na liturgický a modlitební život, který byl v západní klášterní tradici později pomalu nahrazován specializací na určitou činnost, tvoří jádro etiopské klášterní tradice.“ Václav JEŽEK, Křestanská tradice v Etiopii, Kypr: Askas leukósia, 2013, s. 62-63.

59 „Svátosti nám nechtějí vyčarovat zdravý svět. Nejsou ani drogou, ani magií. (...) Jako osobní setkání se Spasitelem uprostřed jeho církve mohou však svátosti rozhodujícím způsobem přispět k uzdravení jednotlivce v ještě neuzdraveném světě." Michael MARSCH, Uzdravování skrze svátosti, Praha: Portál, 1992, s. 20. 
kdo je vede, k projevům hysterie, strojenosti, teatrálnosti anebo senzacechtivosti. “60

Po více než padesát let se katolická církev také aktivně zapojuje do ekumenického hnutí, které má rovněž vliv na spiritualitu mnoha věrících. ${ }^{61}$ Kanonické právo stanoví v této oblasti nejen možnosti, nýbrž i hranice, o čemž svědčí například velmi omezená možnost svátostného interkomunia, zejména s křestany církví pocházejících z protestantské reformace: „V nebezpečí smrti nebo podle rozhodnutí diecézního biskupa nebo biskupské konference v jiné naléhavé závažné nutnosti udělují katoličtí udělovatelé tytéž svátosti (smiŕ̌ení, Eucharistie a pomazání nemocných) také ostatním křestanům, kteří nejsou v plném společenství s katolickou církví, jestliže se nemohou obrátit na udělovatele ze svého společenství, jestliže sami o to požádají a pokud o těchto svátostech projeví katolickou víru a jsou řádně připraveni. “62 „Eucharistická pohostinnost“ (eucharistische Gastfreundschaft) je př́liš citlivou otázkou také pro pravoslaví, a proto není vhodné ji považovat za potřebnou a aktuální, ${ }^{63}$ jestliže formy spirituálního obohacování i sbližování mohou být jinak velmi rozmanité.

\section{Svátostná spiritualita}

Kanonické právo katolické církve se oproti civilnímu právu vyznačuje specifikem rozlišování právních úkonů na platné (validitas) a dovolené (liceitas). Nesplnění podmínek dovolenosti samo o sobě nezpůsobuje neplatnost. Je to patrné např́íklad v základním ustanovení Kodexu kanonického práva ohledně osoby vysluhovatele Eucharistie: „Celebrantem, který v Kristově osobě může slavit svátost Eucharistie, je pouze platně vysvěcený kněz (sacerdos valide ordinatus). Dovoleně (licite) koná Eucharistii kněz, kterému v tom nebrání kanonický zákon (...)“64

Platnost a dovolenost jsou však pouze předpokladem právně relevantního jednání v církvi. Vzhledem $\mathrm{k}$ tomu, že právní úkony bývají nezřídka zároveň úkony duchovními, kodex navíc zavádí kategorii duchovního užitku (utilitas), ba "plodnosti“ (fructuositas), takže pastýřrum se např́klad v oblasti manželského práva ukládá úkol „užitkuplně liturgicky slavit svátost manželstvi“ a tak „dát najevo, že manželé naznačují a podílejí se na tajemství jednoty a plodné lásky mezi Kristem a církví ${ }^{65}$ Prvky platnosti a dovolenosti však nelze uměle stavět proti duchovní podstatě slavení manželství; jsou totiž nutným předpokladem toho, aby se oddavky děly v rámci řádu stanoveného církví a právě v tomto kontextu posloužily duchovnímu prospěchu nupturientů, jejich osobní spiritualitě..$^{66}$

60 Instrukce Kongregace pro nauku víry o modlitbách za získání uzdravení od Boha z 1. září 2000. Disciplinární nařízení, čl. $5 \$ \$ 2,3$, in: Acta České biskupské konference 4/2009, s. 75-87, s. 85-86.

61 „Některé aspekty křestanského tajemství byly leckdy postaveny do jasnějšího světla v jiných církvích nebo církevních společenstvích. Duch svatý zvláštním způsobem obohatil jejich četbu a rozjímání Písma svatého, různé formy veřejné bohoslužby a osobní zbožnosti i rozličné výrazy křestanského svědectví a svatosti života." Walter KASPER, Duchovní ekumenismus. Praktické podněty $k$ jeho uskutečňování, Kostelní Vydří: Karmelitánské nakladatelství, 2008, s. 14.

62 CIC 1983, c. $844 \$ 4$

63 „Z pohledu pravoslavné teologie není Eucharistie pouze individuálním úkonem, odděleným od dalšího života v církvi. Přemýšliví členové pravoslavné církve si v žádném př́ipadě nedokáží představit Eucharistii oddělenou od plnosti své církve, tj., že někdo z tohoto hlediska cizí by v ní mohl přijímat Tělo a Krev Kristovu bez toho, že by plně akceptoval společenství, které slaví tajemství, a bez plné zavázanosti vưči němu, zejména však s ohledem na víru církve, která je a zůstane neměnná. Jinak řečeno, neexistuje separace mezi církví a Eucharistií. Kdo chce mít jedno, musí mít i druhé.“ Štefan PRUŽINSKÝ, Aby všetci jedno boli. Pravoslávie a ekumenizmus, Prešov: Metropolitná rada Pravoslávnej cirkvi na Slovensku, 1997, s. 279.

64 CIC 1983, c. $900 \$ 1$ et 2.

65 CIC 1983, c. $10633^{\circ}$.

66 „Dimenze sakramentality představuje pro křestany velké a nezasloužené povolání, zároveň však i velmi náročný úkol. (...) Celá svatební liturgie se tak stává místem radostného a vděčného slavení celého Božího plánu, kdy při jeho realizaci Bůh skutečnosti stvoření hodnotí jako ,dobré, avšak pouze po stvoření člověka jako muže a ženy vidí Bůh své stvoření jako ,velmi dobré (Gn 1,31).“František KUNETKA, Matrimoniální obřady římské liturgie v proměnách a konstantách dějinného vývoje, in: Walerian BUGEL a kol., Obřady manželství v různých liturgických tradicích, Olomouc: Univerzita Palackého, 2013, 75-95, s. 95. 
Náležitou právní úpravu si vyžaduje rovněž jednání tak duchovní a intimní, jakým je slavení svátosti smíření. Pouze na první pohled se zdá být paradoxní, že právě tato svátost vyžaduje stanovení mimořádně komplexního právního rámce. ${ }^{67}$ Také zde totiž nelze stavět do kontrastu spirituální a právní rozměr svátosti, nebot’ ve hře jsou především záruky ochrany kajícníka, jichž nelze dosáhnout bez pevně zakotvených disciplinárních prostředků; zároveň je však nesprávné, pokud sami kajícníci zabředají do strnulého juridismu. ${ }^{68}$ Současná právní úprava již nehovoří o zpovědníkově jurisdikci, nýbrž o jeho pověření (facultas), nebot' se zde jedná o působení na specifickém vnitřním fóru, totiž v oblasti svědomí (forum internum). Toto pověření je sice předpokladem platnosti zpovědi, avšak samo kanonické právo zároveň vybízí zpovědníky k prrístupu, který by podnítil duchovní užitek kajícníků: „Při udílení svátosti smíření je kněz pamětliv, že je tu soudcem i lékařem a služebníkem Boží spravedlnosti a současně milosrdenství, ustanoveným od Boha, aby usiloval o Boží čest a spásu duší. “69

Právě tak pojímá zákonodárce proporce slavení samotné svátosti Eucharistie. Jistěže je zde především zřetelně stanovená podmínka platnosti: „Celebrantem, který v Kristově osobě může slavit svátost Eucharistie, je pouze platně vysvěcený kněz. “70 Neschází však rovněž aspekt duchovního prospěchu, který navíc v př́padě slavení této svátosti nabývá výrazného komunitního rozměru: „Slavení Eucharistie se uspořádá tak, aby z ní měli všichni účastníci co největší užitek, pro který Kristus Pán eucharistickou obět ustanovil." ${ }^{\text {"71 }}$

Zásadní úloha Eucharistie v životě církve má být zřetelně artikulovaná již při výchově budoucího kléru: „Slavení mše svaté je středem veškerého života semináře, takže studenti denní účastí na Kristově lásce čerpají především $\mathrm{z}$ tohoto velmi bohatého pramene duševní sílu pro apoštolát a pro svůj duchovní život." ${ }^{\text {"72 }}$ Osobní vztah k eucharistickému tajemství patří k projevům autentického kněžského povolání, bez něhož by neměla smysl observance všech právních i liturgických předpisů. ${ }^{73}$

Liturgickým slavením a přijímáním se eucharistická spiritualita nevyčerpává, nebot ve druhém tisíciletí se na křestanském Západě postupně rozvíjely různé formy eucharistické úcty mimo mši, především eucharistické adorace a procesí. Také zde není přehnané hovořit o spirituálním rozměru, který je hlavním nositelem potřeby prŕslušné kanonickoprávní úpravy. ${ }^{74}$ Rozmanité podoby takových pobožností potvrdil první Kodex kanonického práva: „V kostelích anebo kaplích, v nichž je dovoleno uchovávat Nejsvětější Eucharistii, možno konat soukromý výstav či se schránkou z jakéhokoli pádného důvodu bez svolení ordinářova; veřejný výstav či s monstrancí pak o svátku Božího Těla a během jeho oktávy ve všech kostelech při mši sv. a při nešporách; jindy pak jen z pádného a vážného důvodu, zejména veřejného, a se svolením místního ordináře, i když

67 CIC 1983, c. 959-991.

68 „Osobní chápání hříchu a svátosti smírení při zachování právního rámce ustanoveného církví od nás žádá daleko více než právní přístup. V osobním proživání zpovědi nejde jen o několik úkonů, byt upřímně a angažovaně vykonaných, nýbrž spíše o rozhodnutí zacelit hříchem porušenou skutečnost novým zásadním činem (...). “ Józef AUGUSTYN, Sviatost zmierenia. Inšpirácia nielen pre zpovedníkov, Trnava: Spolok svätého Vojtecha, 2015, s. 16.

69 CIC 1983, c. $978 \$ 1$.

70 CIC 1983, c. $900 \$ 1$

71 CIC 1983, c. $899 \$ 3$.

72 CIC 1983, c. $246 \$ 1$.

73 „Znovu se vás bohoslovců ptám: je každodenní mše svatá srdcem vašeho dne? Pokud vám nahání hrůzu, pokud se jí neúčastníte pravidelně, pokud jste pasivní a rozmrzelí nebo je to jen okrajová část vašeho dne a ne jeho středobod - jde o znamení, že nejste ke kněžství povoláni.“ Timothy M. DOLAN, Kněži pro třetí tisíciletí, Brno: Kartuziánské nakladatelství, 2016, s. 221.

74 „Středověký obrat způsobil určité ztráty. Na druhou stranu ovšem umožnil podivuhodné prohloubení duchovního života. Ukázal velikost tajemství darovaného při Poslední večeři, a umožnil ho nově a úplně zakusit. Kolik svatých - právě těch, kteří se vyznačovali láskou k bližnímu - bylo živeno touto zkušeností a bylo vedeno vstříc Pánu! Toto bohatství nesmíme ztratit!" Joseph RATZINGER (BENEDIKT XVI.), Duch liturgie, Brno: Barrister \& Principal, 2006, s. 80. 
kostel př́sluší vyňaté řeholi. “75 Také kodex z roku 1983 vyjadřuje v této záležitosti kontinuitu: „Doporučuje se, aby se v těchto kostelích a kaplích každoročně konal slavnostní výstav Nejsvětější svátosti po vhodnou dobu, i když nesouvislou, aby místní společenství více meditovalo a klanělo se eucharistickému tajemství; takovýto výstav se koná pouze tehdy, jestliže se předvídá náležitá účast věřících, a zachovávají se stanovené normy. (...) Kde je to podle rozhodnutí diecézního biskupa možné, koná se za účelem veřejného svědectví úcty k eucharistii, především o slavnosti Těla a krve Páně, průvod veřejným prostranstvím. ${ }^{\text {“76 }}$

\section{Závěrem}

„Boholidskost“ církve je příčinou toho, že vnější projevy duchovní zkušenosti věřících mohou být zároveň $\mathrm{v}$ mnoha aspektech uchopitelné a regulovatelné kanonickým právem. Děje se to na rovině kolektivní i individuální. Církev je „, tomto světě ustavená a uspořádaná jako společnost“,77 platí pro ni všeobecný princip ubi societas ibi ius. Viditelnou společností je navíc nejen církev jako celek, nýbrž také nejrozmanitější formy církevního sdružování věrících. Zejména zasvěcený způsob života plní nejlépe svoji úlohu v církvi právě tehdy, pokud se dodržuje jeho regula, a to nejen abstraktně pojatý „duch“, nýbrž i jemu odpovídající „litera“. Jednotlivým skupinám věřících i věř́cím jako jednotlivcům zaručuje kanonickoprávní úprava právo na vlastní obřad i na spiritualitu podle osobní duchovní volby, avšak za zcela zásadní podmínky: „pokud je v souladu s učením církve“ ${ }^{78}$ Liturgické i svátostné úkony věřících jsou pak nejen projevem jejich duchovního života, nýbrž zároveň právně upraveným jednáním. Kanonické právo zde chrání jednotnou disciplínu, která utvárí atmosféru předvídatelnosti a stability, svědčící prožívání osobní spirituality rozhodně více než zmatek a svévole. 


\title{
Kanonické právo a spiritualita
}

\begin{abstract}
Abstrakt
Cílem článku je poukázat na užitečnost kanonického práva pro duchovní život věrících a vyvrátit zakořeněnou představu, že právo spiritualitu spíše umrtvuje nebo brzdí. Nejprve postupuje historicky a uvádí př́iklady církevní disciplíny, které se v dějinách prokázaly jako významná pomoc prožívání spirituality, zejména zasvěcený zpưsob života. Dále poukazuje na obřadové bohatství východních církví i na problémy spjaté s liturgií křestanského Západu a uvádí právní prostředky, které zajištují, aby se liturgická praxe vykonávala k duchovnímu prospěchu věrících. Podrobněji pak analyzuje různé formy zasvěceného života a způsob, jakým je pojímá kanonické právo. Předmětem zkoumání jsou pak sdružení laiků, nová hnutí v církvi nebo ekumenismus. Ve svátostné disciplíně církve se kanonické právo projevuje nejen jako záruka platnosti a dovolenosti právních úkonů, nýbrž především jako předpoklad duchovního užitku svátostného života pro věřící.
\end{abstract}

Klíčová slova: kanonické právo, spiritualita, zasvěcený život, liturgie, svátosti

\section{Kontakt na autora}

doc. JUDr. Stanislav Přibyl, Ph.D., JCD

Jihočeská univerzita v Českých Budějovicích

Teologická fakulta, Katedra teologických věd

Kněžská 8, 37001 České Budějovice

pribyl@tf.jcu.cz 